\title{
DEMOGRAPHIC CHANGE AND ITS IMPACT ON FISCAL GOVERNMENT IN INDONESIA
}

\author{
Salman Samir, Achmad Rifa'i, Listiono, Irwandi, Maizul Rahmizal \\ Master of Science in Economics Program, Faculty of Economics and Business, \\ Universitas Gadjah Mada \\ Nusantara Bulaksumur Street, Kampus UGM, Yogyakarta 55281, Indonesia
}

\begin{abstract}
Indonesia experiences demographic change because of basically the result of successful policies in the past. Especially in the health sector where in the era of Orde Baru ${ }^{1}$ the family planning program was successfully implemented. Productive age over non productive age are the two main variables in addition to some other variables that are also shaping demographic change. This study highlighted the demographic changes, particularly with the increasing burden of government dependents in the allocation of education, health, and social security. This study attempted to see the effect of demographic change on government fiscal using the Error Correction Model. The choice of this model was because ECM could be used to see the short-run dynamic relationship of variables that have cointegration relationship. The results showed that there are cointegration so that it could be continued by estimating using ECM and the results show that demographic change have an influence on government fiscal where proxies used such as mortality, birth rate, life expectancy have significant effect while productive and non-productive age have no significant effects.
\end{abstract}

\section{Keywords:AgingPopulation;Cointegration;DemographicChange;Error Correction Model; Government Fiscal}

\footnotetext{
1 Orde Baru is Period when Soeharto occupied as The $2^{\text {nd }}$ President of Indonesia
} 


\section{Introduction}

Changes in the demographic structure will have a significant impact on economic performance and government spending. The higher the population of productive age, the greater the potential for economic growth and state revenues. Conversely, when the number of nonproductive age population is higher then the burden of government spending will be more severe. Such as for spending on the education, health and social sectors. When the country's revenues are slightly while government spending increases then it will pose a serious threat to fiscal sustainability. As a country with a large population, it is imperative for the government to be serious in managing state budget as a result of the large population and the amount of allocation for the welfare of the population.

Indonesia as the fourth most populous country in the world (World Bank, 2017), ofcoursemustbewaryofthis demographic problem. By 2015, the proportion of the productive age population is 67.13 percent, while the under-productive age is 27.69 percent and the age above 65 years is 5.17 percent. In general, the number of people of productive age and age above 65 years continue to increase, on the contrary, the number of underaged population continues to decline. Of course in the next few years this condition will be very different, where the amount of productive age will be reduced, while the age above 65 will grow. If the government does not take seriously the issue will be a boomerang for the country not only in terms of the number of productive age that is not absorbed and maximally empowered to contribute to increase economic growth but also when more and more unproductive age will add to the burden of the state in terms of expenditure to ensure its survival.

\section{Picture 1. Growth of Indonesian Population by Age}

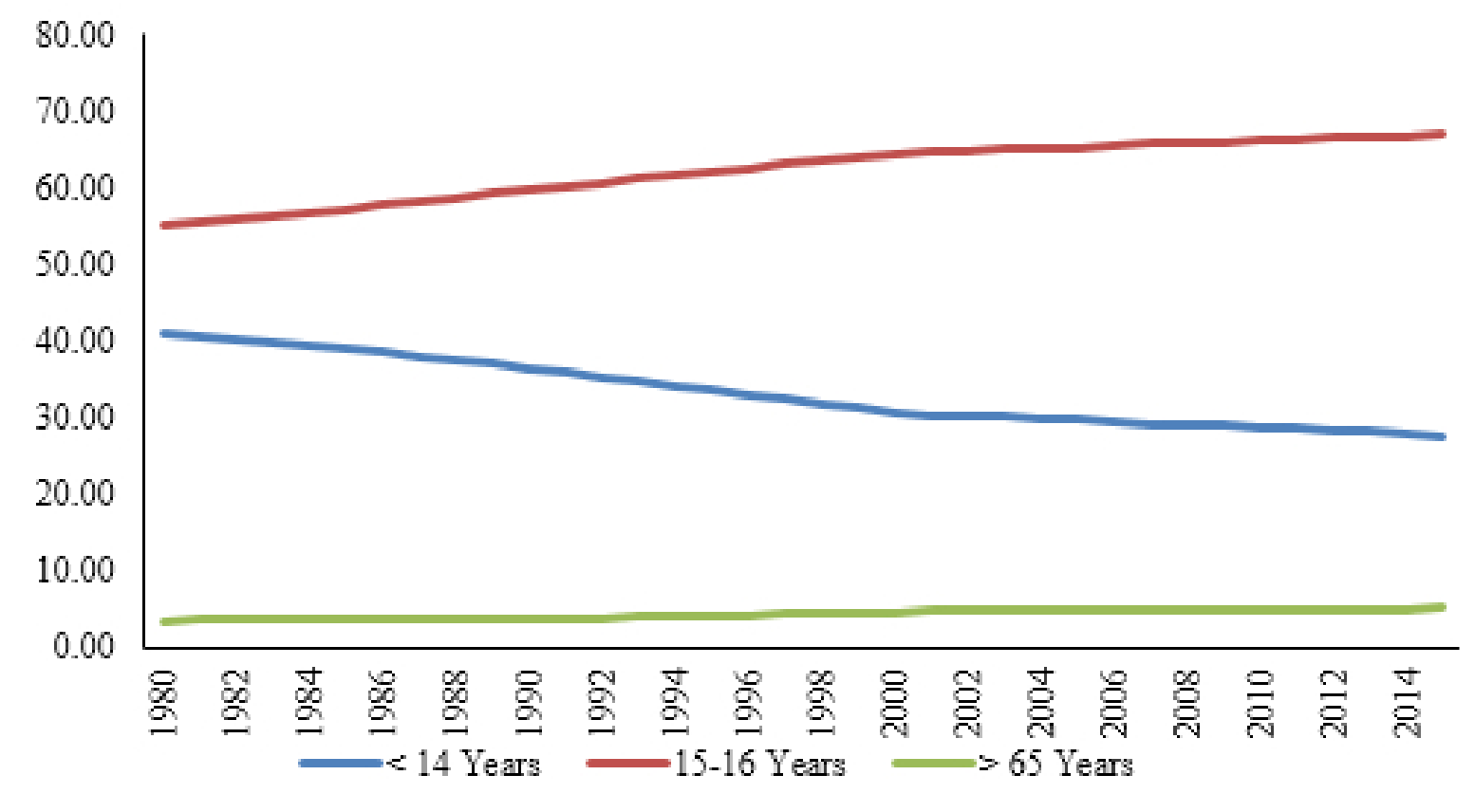

Source: Indonesia Central Bureau of Statistics 
In addition, from year to year life expectancy in Indonesia is increasing, where in 2015 reached the age of 70.84 years. According to the Ministry of Health, the high number of life expectancy is one indicator of the success of the national development of health (InfoDatin, 2016). The increasing life expectancy of the Indonesian population is one reflection of the success of the government program, but on the other hand if it is not managed properly it can create new problems.

Changes in the demographic structure have a significant impact on fiscal sustainability, Lee, et. Al (2016). Firstly, the income of the state is determined by the productive age population, the higher the productive age population, the greater the potential of state revenues, especially through the tax sector. Secondly, government spending, especially on education, health and social sectors is also influenced by non-productive age population, under 15 years or over 65 years.

\section{Picture 2. Spending for Health, Education and Social Sectors}

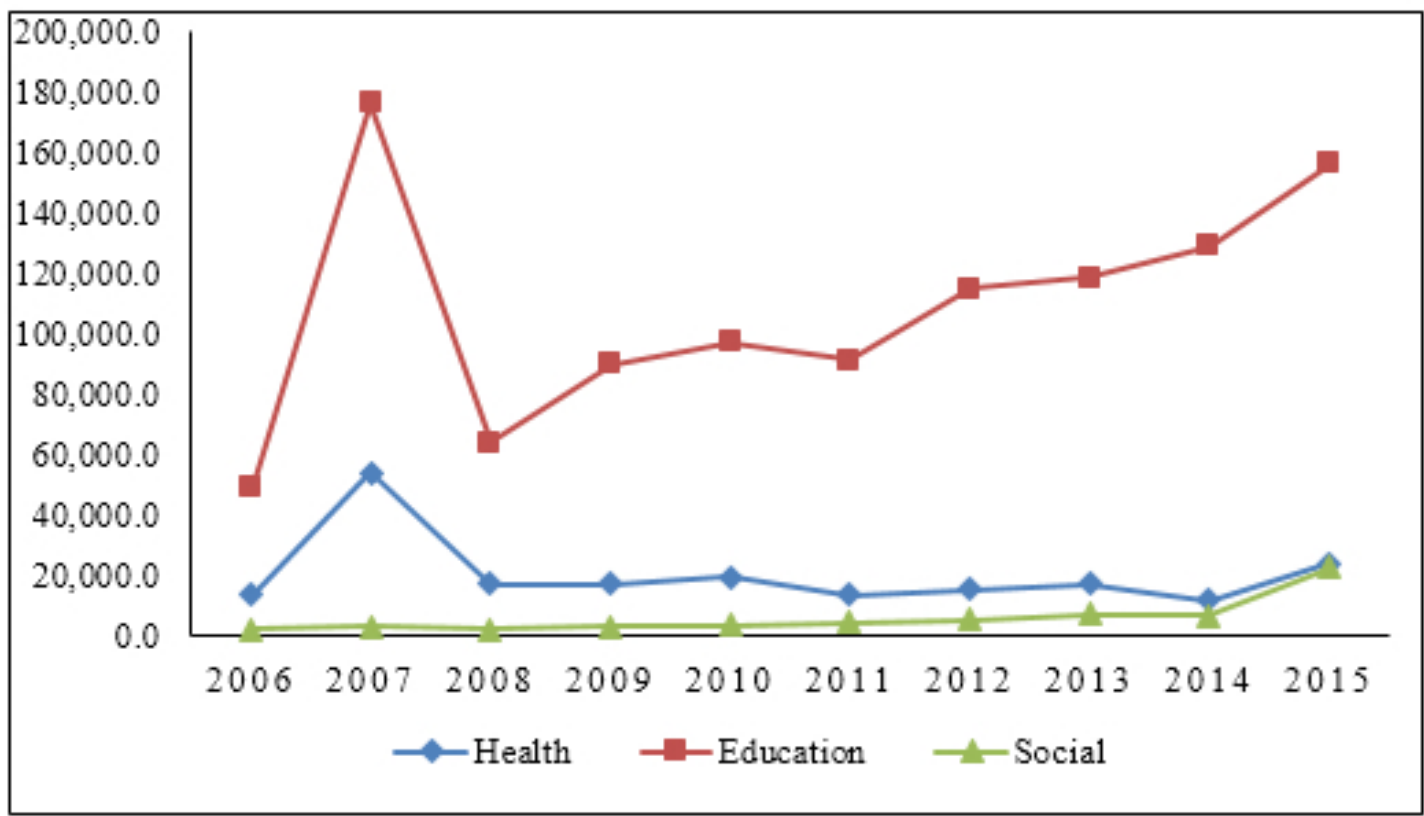

Source: Finance Note and State Budget Indonesia (in million)

Based on the picture above shows that in the last ten years government spending on health, education and social protection has increased. Expenditures for the education sector are budget allocations directed to people under the age of productive, while health and social allocations are more widely allocated for people below and above the productive age.

According to Rajan, Giap \& Yan (2014), there are three fiscal indicators that can be used to measure fiscal risk. First, it deals with fiscal variables such as debt, interest rate growth, and primary equilibrium. Second, it deals with demography and government spending. Third, it relates to government assets and obligations. Therefore, as the problems described above, the researcher is interested to see how the effect of demographic structure changes on government spending on education, health and social sectors in Indonesia. 


\section{Literature Review}

Some of the previous researches tried to explain the government fiscal with the problem of demographic structure change which is currently felt by many countries especially, aging population. This problem is natural and will occur in many countries. The advancement of education, health, economics and technology into several factors that encourage some people to delay marriage or at least have only one child in a family because of the increasing competition in the future especially in the economic field. This has an impact on the changing characteristics of the demographics of a country where the age of the young population grows slowly while the age of the aging productive population is not replaced by the young population proportionately because of low birth rates while the better health facilities make the aging population increasing which they are no longer productive. Sriyana (2008), said that the nature of the trend towards aging population is characterized by a slower pace of young population growth than the growth of the elderly population. The slow growth of young people's age is due to the decline in birth rates while the rate of growth of the elderly population is due to the increase in life expectancy.

Castro (2016) explains that trends in ageing populations tend to drive a significant drop in savings rates with reduced saving rates will lead to a surge in real interest rates worldwide with the unavoidable impact on global investment and technical advances that limit the potential for output growth. According to Eskesen (2002), when the average age of the population increases then the impact on spending on pensions, health care and long-term care will increase. At the same time, depreciation in the number of participants of the workforce will reduce taxes and income social security contributions. Meier and Werding (2010) explained that the impact of aging population on the most basic state welfare is on how far the state is involved in the provision or financing of health care, long-term care as well as the provision of children's needs, education, and financial assistance to families. Seen from some of the above explanations, an aging country will face the burden of pensions and the burden of the provision of heavier public facilities in order to maintain long-term levels of health and care services so that it will become more difficult to maintain a system of fiscal sustainability as a result the occurrence of aging population.

Several previous research results related to ageing population on fiscal sustainability have also been conducted by other researchers. Lee (2016) conducted a study using government revenue variables, government spending, and ageing populations on fiscal balance in Asia. From his research, Lee projected those variables until 2050 using the Simple Stylized Model and National Transfer Accounts data set. From the results of his research, known that the aging population affects the increase in public spending and lower government revenue. In his research, Eseksen (2002) found that Austria is not so ready to face the fiscal burden of ageing populations and lead to fiscal sustainability threatened, even with fairly optimistic assumptions about the impact of pensions and labor market reform. As a consequence, in order to maintain long-term fiscal sustainability, reforms in pensions must be run further and savings from other sources may be needed.

Research conducted by Ito and Rose (2010), shows quite different things. In their paper, they focus on examining the impact of demographic change on spending on the education sector. 
From the conclusions described it turns outexamined the e $\square$ ects of demographic change on compulsory education costs using prefectural panel data from 1975 to 2005 in Japan. If the elderly are self-interested and short-term decision makers, they would try to reduce government expenditure on compulsory education. On the other hand, the elderly would try to enhance public education costs if they are altruistic or long-term decision makers. From the estimation results indicate that the higher share of the elderly in-creased the expenditure on compulsory education per student by local governments in the 1980's. However, this relationship was reversed in the 1990's. They did not find evidence that this change was caused by the change in the living arrangements of the elderly in Japan. Thus, we suspect that the change in the relationship between public education costs and population aging was caused by the changes in the fiscal system, which increased the discretionary power of the local governments in determining public education costs.

It is still in Ito and Rose, then they propose three issues are pointed out for future research. Firstly, we need a detailed analysis of the effects of the changes in the subsidy system on compulsory education and on the relationship between population aging and public education costs. Secondly, a municipal level analysis would be more useful since there are many more variations in both demographic and education costs. Thirdly, both the quality of education and demographic change should be analyzed directly.

In contrast to the research conducted by Dintras (2014). In his paper entitled demographic transition and public policy in Chile where the period of transition time of demography in paper is 150 years. Explained that the result suggest a correlation between demographic variables and fiscal expenditure on different goods. Particularly, the estimations find a positive impact of a younger population on educational expenditure adn negative effects of the share of adult population on fiscal expenditure. As many other countries has experienced demogrpahic changes over the past years. These changes influenced many spheres of society's life, changing the environment and incentives faced by different agents in economy. The government hs been greatly affected by these changes, responding with the implementation of different policies throughout the years. The effect of demographic transition on fiscal policies were assessed using a framework where the government acts as complement to the private sector in th proviion of certain goods. The model highlights not onl the relevance of the changing demands from diverse segments of the population, but aksi the importance of the private sector in determining government's expenditure. From the empirical results, support the conclusion suggested by the model. Particularly, it is found a negative effect of the adult population in the public xpenditure and a positive impact of the expenditure in specific goods when the population demanding the good is relatively more abundant

Mateo (2010) conducted a Canadian study of age-related populations in which the results showed that the 65-year-olds (or more) in Edward Island Province had a positive and significant impact on increased government spending on health. While in the other four provinces (Newfoundland, Quebec, Manitoba, and Saskatchewan) are negative and significant because the aging problem is also close to the problem of death. 


\section{Data and Methodology}

This study used annual time series data from 1980 to 2015. Data were obtained from various sources. For life expectancy data obtained from the Central Bureau of Statistics, death rate, birth rate, productive and non-productive obtained from the World Bank, while the data of government spending for the health, education and social sectors derived from the Finance Note of the State Budget.

Tabel 1. The Identity of Variables

\begin{tabular}{|l|l|}
\hline Variable & Identity \\
\hline Government Expenditure & $\begin{array}{l}\text { Total government expenditures for education, health, and social } \\
\text { sectors }\end{array}$ \\
\hline Birth rate & $\begin{array}{l}\text { The estimated average age in a person on the basis of the mortality } \\
\text { rate of that period that tends to remain unchanged in the future } \\
\text { (Indonesia Health Profile, 2012) }\end{array}$ \\
\hline Death rate & $\begin{array}{l}\text { Figures showing the number of live births in a given year per 1,000 } \\
\text { inhabitants by mid-year (Indonesian Health Profile, 2012) }\end{array}$ \\
\hline Non productive & $\begin{array}{l}\text { Figures showing the magnitude of deaths occurring in a given year } \\
\text { for every 1,00o residents }\end{array}$ \\
\hline Productive & Number of population aged o-14 years and age above 65 years \\
\hline
\end{tabular}

To see the relationship between demographic change variables and total government spending on health, education and social sectors is used the Error Correction Model (ECM). This is because ECM can be used to see shortrun dynamic relationships of variables that have cointegration relationships (Saunders, 1997). The estimation stages are the unit root test, cointegration test, and ECM. The root unit is used to view the stationarity of the data used in the model. This is to ensure that estimates are avoided from spurious regression problems. As stated by Gujarati (2009) that the regression of the non-stationary variables will produce spurious regression. The cointegration test is used to see if the variables within the model have a long-term relationship. Engle Granger states that if two series have long-term relationships, then ECM can explain the dynamic changes that occur in the short term (Pal \& Mittal, 2011). The model is as follows.

$\Delta$ Log Expenditure $e_{t}=\alpha_{0} c+\alpha_{1} \Delta B$ Birth $h_{t}+\alpha_{2} \Delta$ Death $h_{t}+\alpha_{3} \Delta L$ LifeExp $p_{t}+$ $a_{.4 \Delta l o g}$ Productive $_{t}+a_{5} \Delta$ logNonProductive $_{t}+E_{c t}(-1)+\mu_{t}$

\section{Results and Discussion}

\section{Unit Root and Cointegration Tests}

The result of unit root test with Augmented Dickey-Fuller showed that two variable (stationary and birth rate) are stationary at the level, while other variables (government expenditure, productive age and non-productive age) are stationary at first difference level. Unit-root test results are presented in the table below with different levels of significance for each variable in the study.

Tabel 2. The Result of Unit Root Test

\begin{tabular}{|l|c|c|}
\hline Variable & Tes of ADF & $\begin{array}{l}\text { Order of Inte- } \\
\text { gration }\end{array}$ \\
\hline Government Exp (Log) & $-6.079 .104^{* * *}$ & $\mathrm{I}(1)$ \\
\hline Life Expectancy & $-9.754 .452^{* * *}$ & $\mathrm{I}(1)$ \\
\hline Birth Rate & $-3.560 .189^{* *}$ & $\mathrm{I}(0)$ \\
\hline Death Rate & $-5.050 .680^{* * * *}$ & $\mathrm{I}(0)$ \\
\hline Productive (log) & $-2.185 .864^{* *}$ & $\mathrm{I}(1)$ \\
\hline Non productive (Log) & $-1.990 .664^{* *}$ & $\mathrm{I}(1)$ \\
\hline $\begin{array}{l}\text { note: }{ }^{* * *} 1 \%, * * \\
\text { 10\%, }\end{array}$ & & \\
\hline
\end{tabular}


Tabel 3. The Result of Cointegration Test

\begin{tabular}{|c|c|c|c|c|}
\hline Hypothesized & & Trace & 0.05 & \\
\hline No. of CE(s) & Eigenvalue & Statistic & Critical Value & Prob. ${ }^{* *}$ \\
\hline None * & 0.970178 & 270.7225 & $95 \cdot 75366$ & 0.0000 \\
\hline At most 1 * & 0.781239 & 151.2969 & 69.81889 & 0.0000 \\
\hline At most 2 * & 0.770329 & 99.62455 & 47.85613 & 0.0000 \\
\hline At most $3 *$ & 0.648919 & 49.60684 & 29.79707 & 0.0001 \\
\hline At most 4 & 0.334455 & 14.01776 & 15.49471 & 0.0825 \\
\hline At most 5 & 0.005125 & 0.174700 & 3.841466 & 0.6760 \\
\hline
\end{tabular}

Trace test indicates 4 cointegrating eqn(s) at the 0.05 level

* denotes rejection of the hypothesis at the 0.05 level

**MacKinnon-Haug-Michelis (1999) p-values

Meanwhile, for cointegration test indicates the existence of four rank cointegration, where the result is then reduced by the number of stationary variables at I (o), thus it can be concluded that there is a long-term relationship between the variables in the model. Cointegration test results can be seen in the table below.

\section{ECM Estimation}

When the variables have a cointegration relationship (long term) then to see the short term behavior of the long term value can use error term in Error Correction Mechanism Model
(Ghozali \& Ratmono, 2013). From the results of cointegration tests that have been done in this study, shows that in the model there is a cointegration relationship. Thus the next estimate is with the ECM model.

The estimation results showed that 44 percent of variation in the total variable of government spending for three sectors can be explained by the variable of birth rate, mortality, life expectancy, non productive age and productive age. The Durbin-Watson value of 1.847 indicates no autocorrelation between residuals. A negative value on error correction term (ECT) confirms a long-term balance of relationships in the model. The speed

Tabel 4. The Result of ECM Estimation

\begin{tabular}{crrrr}
\hline Variable & Coefficient & Std. Error & t-Statistic & \multicolumn{1}{c}{ Prob. } \\
D(Birth) & 1.366 .815 & 0.614670 & 2.223 .655 & 0.0344 \\
D(Death) & -7.916 .111 & 3.927 .866 & -2.015 .372 & 0.0536 \\
D(LifeExp) & -0.116135 & 0.025757 & -4.508 .847 & 0.0001 \\
D(LOG_Nonproductive) & -3.646 .254 & 3.000 .097 & -1.215 .378 & 0.2344 \\
D(LOG_Productive) & -5.581 .012 & 4.565 .219 & -1.222 .507 & 0.2317 \\
ECT & -0.406627 & 0.144425 & -2.815 .487 & 0.0088 \\
C & 1.589 .056 & 0.917192 & 1.732 .523 & 0.0942 \\
\hline
\end{tabular}


of adjustment to long-term balance is 40 percent, this is indicated by the coefficient value of ECT of 0.406 .

\section{Relationship of Demographic Change With Government Fiscal}

The estimation results of the effect of demographic changes on government fiscal finds that the demographic change process has resulted in various negative impacts on government spending. Government spending continues to increase in various components related to demographic changes, namely education spending, health, and social security

The results of the analysis indicate that the birth rate is positively significant to the total fiscal government for the three sectors of education, health and social security. This means that the greater the birth rate will be the greater the government spending for these three sectors. The positive influence between birth rate and government spending in Indonesia is inseparable from the amount of composition for education sector spending. Throughout the study period, the composition of educational spending was quite high, on average about 70 percent of total spending for three sectors. Education spending is aimed at the school-aged population, so the greater the birth rate the need for the cost of education will increase. Given that the education sector is the most vital sector for the sustainability of a country, it is certainly very reasonable that the allocation of expenditures in this sector is always increasing, especially with the increasing number of Indonesian population every year. In addition, the age of $0-15$ years also absorbs a considerable budget from the health sector. From health spending some of the goals expected by the government are: First, to improve the quality of maternal, child and reproductive health services. Second, to improve the handling of people's nutritional problems. All three hold higher education and health human resources quality growth. As shown in the figure below where spending on education, health, and social security is likely to increase every year. The figure below shows the increased likelihood of spending on the education, health and social security sectors.

\section{Picture 3. Government Spending on Social, Education and Health Sectors}

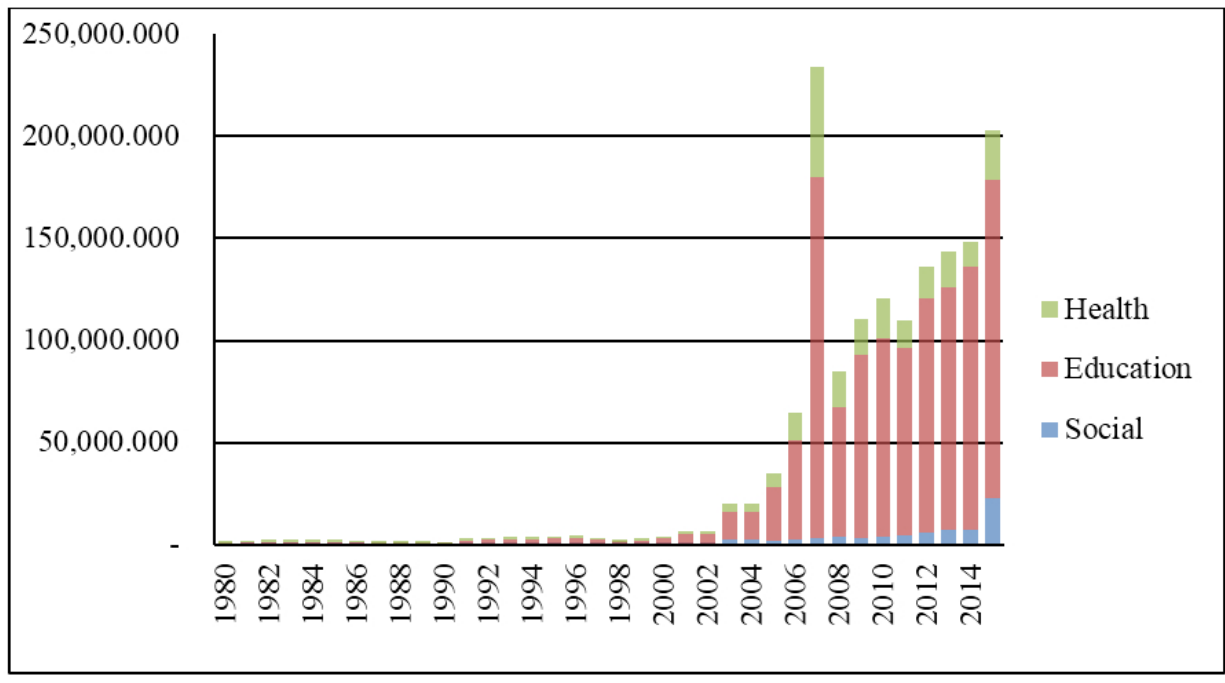

Source: Finance Note and State Budget Indonesia (in million) 
The mortality rate is negatively significant to government fiscal, meaning that when the mortality rate increases, government spending on three sectors will be reduced, especially in the social security sector. On the contrary, when the mortality rate is reduced, government spending on three sectors will increase. This means that the cost of government will be greater when the population is also large, whether it is to improve public health, education and social. However, in reality the proportion of mortality tends to always decline year by year so that of course this will affect the increase of government spending for babies born in Indonesia. The decline in infant mortality rate is a very positive thing in terms of health in which Indonesia succeeds in reducing infant mortality due to health sector policies but from the economic side will have an impact on government spending which will tend to increase due to the allocation of education, health and social security funds Up every year. The following data on infant mortality figures as in the Indonesia Central Bureau of Statistics report.

\section{Picture 4. The Infant Mortality Rate in Indonesia 1971 - 2012}

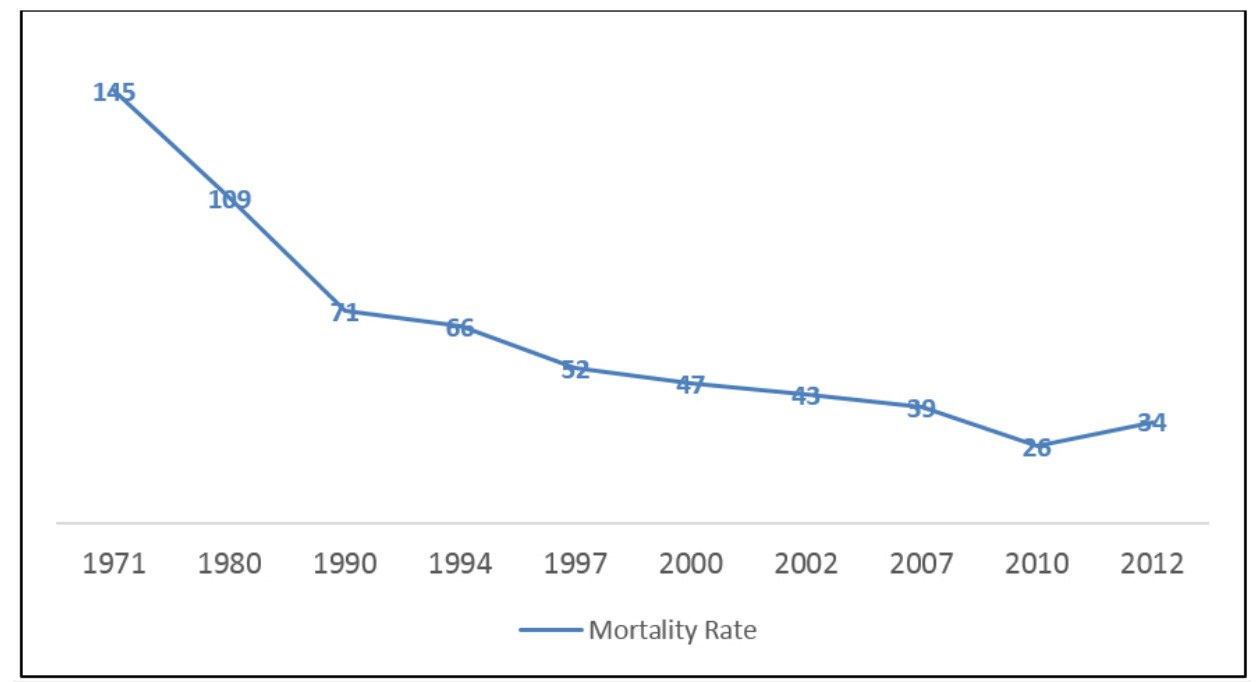

Source: Indonesia Central Bureau of Statistics

Life expectancy has a significant negative effect on total government spending for three sectors. This means that the higher life expectancy then the total government spending for the three sectors will be reduced. This condition is of course related to the health of the elderly population, where the indicator is the number of morbidity. Based on data from the health ministry, in general the morbidity of the Indonesian population has decreased, meaning that the health of the elderly population has increased. In 2014 for example, anga morbidity of 25.05 which means of 100 elderly people 25 people of whom experience illness. Thus it can be said that the quality of elderly health in Indonesia is quite good, so the government does not spend much to support elderly health spending. The decline in morbidity is also an indication that before entering old age, the elderly have received adequate health services so that the government no longer needs to 
increase spending because the morbidity rate has shown a declining rate every year as a result of health policy. This can be seen in the following figure.

\section{Gambar 5. The Morbidity Rate in Indonesia}

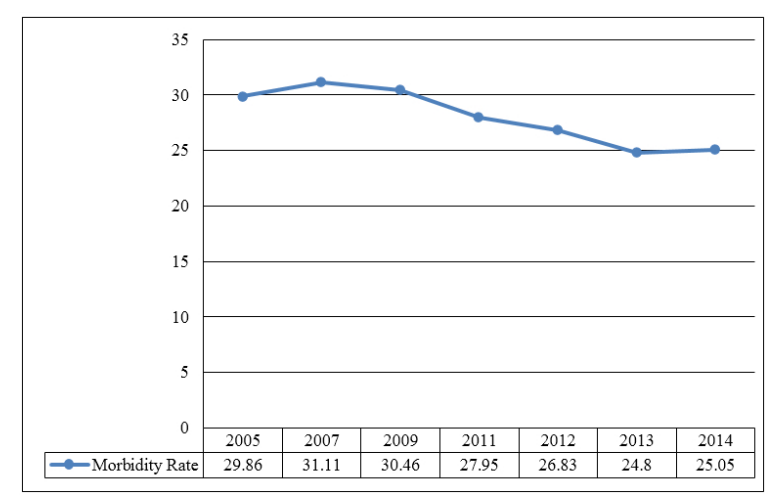

Source: InfoDatin of Ministry of Health of Indonesia

For productive and non-productive ages there are no significant effect on government spending on three sectors. The result of the estimation indicates that the actual non productive and productive age have negative effect, but not significant. In contrast to previous research of Palangkaraya A. Yong (2009) and Matteo (2010) where the results show that age over 65 has a significant negative effect on government spending on health.

\section{Conclusion}

Birth rates are positively related to total government spending on three sectors. Although in the last 35 years the birth rate has decreased, but the government must still anticipate well. On the other hand, the decline in the birth rate will reduce government spending, but in the future this decline will certainly be followed by a decline in the number of productive age population which will affect the state revenue through the tax sector.
The larger the population, the higher the spending should be spent by the government for three sectors. This is reflected in the negative relationship between the death rate and government spending. Being a dilemma for the government, where one indicator of the success of the development program is the decline in mortality otherwise will increase government spending. Meanwhile, the health status of elderly people in Indonesia is quite good, indicated by the negative relationship between life expectancy and government spending. However, health and social budget allocations, especially for the elderly in Indonesia are very small.

\section{Bibliography}

Castro, Gabriela. 2016. Aging and Fiscal Sustainability in A Small Euro Area Economy. Macroeconomic Dynamics Journal. pp. 1-33

Dintras, Pablo Villalobos. 2014. Demographic Transition and Public Policy: Chile 1850 - 2000. Revista de Analisis Economico. Vol. 29, pp. 77 - 110.

Eskesen, Leif Lybecker. 2002. Popuation Aging and Long-Term Fiscal Sustainability in Austria. IMF Working Paper.

Finance Note and State Budget, Ministry of Finance of Republic of Indonesia. 1981 - 2015.

Ghozali, Imam dan Ratmono, Dwi. 2013. Analisis Multivariat dan Ekonometrika: Teori, Konsep dan Aplikasi dengan Eviews 8. Semarang: Diponegoro University.

Gujarati, Damodar N. Dan Porter Dawn C. 2012. Dasat-Dasar Ekonometrika. Jakarta: Salemba Empat.

http://data.worldbank.org/datacatalog/Population-ranking-table 
InfoDatin. 2016. Situasi Lanjut Usia (Lansia) di Indonesia. Ministry of Health of Republic of Indonesia.

Lee, Sang-Hyop., Kim, Jungsuk and Park, Dongyun. 2016. Demographic Change and Fiscal Sustainability in Asia. Springer. o9 Augstus.

Matteo, Livio Di. 2010. The Sustainability of Public Health Expenditures: Evidence from the Canadian Federation. The European Journal of Health Economics, Vol. 11. No. 6 (December), pp. 569-584. Meier, Volker and Martin Werding. 2010. Ageing and Welfare State: Securing Sustainability. Oxford Review of Economic Policy. pp. 655-673

Ohtake, Fumio and Shinpei Sano. 2010. The Effects of Demographic Change on Public Education in Japan. The Economic Concequences of Demographic Change in East Asia. NBER-EASE. Vol. 19, pp. $193-219$.

Pal, Karam and Mittal, Ruhe. 2011. Impact of Macroeconomic indicators on Indian Capital Market. The Journal of Risk
Finance, Vol. 12 Issue: 2, pp. 8497.

Palangkaraya, A., Yong, J. 2009. Population Ageing and its Implications on Agregate Healt Care Demand: Empirical Evidence from 22 OECD Countries. Int. $J$. Healt Care Finance Econ. 9 (4), p.391- 402.

Profile of Indonesia Health, Ministry of Health of Republic of Indonesia, 2012.

Rajan, Ramkishen S., Giap, Tan Khee and Yam, Tan Kong. 2014. Fiscal Sustainability \& Competitiveness in Europe \& Asia. New York: Palgrave Macmillan.

Saunders, Peter J. 1997. Inflation Productivity and Monetary Policy: Are They Related?. Studies in Economics and Finance, Vol. 18 Iss 1 , pp. 3-25.

Sriyana, Jaka. 2008. Dampak Transisi Demografi Terhadap Defisit Fiskal di Indonesia. Jurnal Ekonomi Pembangunan. pp.175-189 